\title{
The Impact of Human Resource Management Practices on
}

\section{Organizational Commitment in the Banking Sector in Kuwait}

\author{
Michel Zaitouni (Corresponding author) \\ College of Business Administration, Gulf University for Science and Technology (GUST) \\ P.O. Box 7207, Hawally 32093, Kuwait \\ Tel: 965-2530-7342Ｅ-mail: zaitouni.m@gust.edu.kw \\ Nabeel N. Sawalha \\ College of Business Administration, Gulf University for Science and Technology (GUST) \\ P.O. Box 7207, Hawally 32093, Kuwait \\ Tel: 965-2530-7341Ｅ-mail: sawalha.n@gust.edu.kw \\ AdilElSharif \\ College of Business Administration, Gulf University for Science and Technology (GUST) \\ P.O. Box 7207, Hawally 32093, Kuwait \\ Tel: 965-2530-7347 E-mail: ElSharif.A@gust.edu.kw
}

Received: December 17, $2010 \quad$ Accepted: February 9,2011 doi:10.5539/ijbm.v6n6p108

\begin{abstract}
In this paper, we investigated the impact of Human Resource Management (HRM) practices on the affective, continuance, and normative organizational commitment among employees in the banking sector in Kuwait. The studywas conducted across permanent, full-time, and part-time employees (managers and non-managers) of five large private banks in Kuwait. Both Exploratory Factor Analysis (EFA) and hierarchical regression analyses were used to draw the relationship between these variables. The results showed that fifty percent of the variables confirmed previous studies and the remaining fifty percent did not support these studies due to factors such as culture and values. The results have a great implication for both the banking industry in Kuwait and international business.
\end{abstract}

Keywords: Organizational commitment, HRM practices, Banking sector of kuwait, Culture, Values

\section{Introduction}

The dynamic nature of human resource management in recent decades affirms the need for more research studies on the impact of human resource practices on employee organizational commitment. Meyer and Allen (1997) believe that the relationship between human resource practices and employee commitment should be examined more fully. They asserted that additional research is needed to identify the antecedents associated with the multiple domains of employee commitment.

It is imperative that management retains its best workers and keeps them committed to the organization in order to attract other quality employees. Therefore, this concept should be the primary focus of researchers in their studies of employment, organizations, and related fields (Scarpello, Ledvinka, \& Bergman, 1995).

The concept of organizational commitment has been investigated and proven to be a consequence of HRM practices in many studies (DeCotiis\& Summers, 1987; Mathieu \&Zajac, 1990). Delaney and Huselid (1996) empirically suggested that fair rewards, competence development, empowerment, recognition and information sharing all affect organizational commitment. Although several studies have been conducted about organizational commitment, ambiguity still exists about the factors affecting the development and promotion of it (Beck \& Wilson, 2001). 
Empirical studies are still needed to detangle the factors leading to organizational commitment. Therefore, based on the deficiency of the prior research, this study attempts to add a valued work to explain the causal linkage between HRM practices and employees' affective, normative, and continuance commitment, supplemented with more appropriate statistical methods to conduct this causal reasoning.

The objective of the present study is to explore the underlying processes and the mechanisms by which HR practices exert influence on employees' commitment. Moreover, this study aims at extending the existing research on organizational commitment by conducting it in a non-western work context focusing on the banking sector of Kuwait.

\section{Literature Review}

The concept of organizational commitment has been subject to numerous studies. These studies have shown that organizational commitment predicts important variables; such as competence, recognition, information sharing and fair rewards (e.g., Allen \& Meyer, 1990; Koys, 1988; Paré \& Tremblay, 2007; Smith, 1995; Whitener, 2001).Previous research also have supported the positive relationship between organizational commitment and selected HR practices (e.g., Mathieu \& Zajac, 1990; Mowday, \& Boulian, 1974).

The following sections will present some theoretical foundation on the organizational commitment and will draw hypotheses for its relationships with various HR practices and control variables. Next, data, measues, methodology, analysis, and results will be discussed. Finally, a conclusion presentation with a discussion section will address limitations, contributions of the study, and the implications for future research.

\subsection{Relationship between personal variables and organizational commitment}

Some research drew results that male employees are more committed than their female counterparts (Knoke, 1988), while other studies found no significant link between the genders (e.g., Igbaria \& Wormley, 1992; Van Dyne \& Ang, 1998). With regard to the education level, some research showed a negative relationship with normative and continuance commitment (e.g. Cohen, 1999; Mayer \& Schoorman, 1998), but others showed no obvious relationship (e.g. Knoke, 1988).

Many scholars in the field considered age as an important factor to predict commitment. Mathieu and Zajac (1990) and Meyer, Allen and Smith (1993) revealed a significant positive correlation mean, 0.2 and 0.36 , between commitment and age. Kaldenberg, Becker and Zvonkovic (1995) indicated that current job attractiveness increases as the employee ages due to fewer other employment options. Hawkins (1998), on the other hand, found an insignificant statistical correlation $(\mathrm{r}=-.004)$ between age and affective commitment for a sample of 396 high school principals.

Meyer and Allen (1997) stated that organizational tenure can lead to contemplative organizational commitment due to the fact that uncommitted workers leave early while the committed ones stay. In another study by Meyer, Allen and Smith (1993), it was found that the new and the senior-tenured employees are more committed than the middle-tenured ones. In addition, Liou and Nyhan (1994) concluded that affective commitment has a negative relationship with tenured employees and continuance commitment had no correlation at all.

\subsection{HR practices and organizational commitment}

Human resource management practices are some, but not all, of the factors that are related to an employee's commitment (Meyer \& Allen, 1997). Although many research studies empirically tried to show the development of a causal relationship (Paul \& Anantharaman, 2004; Ulrich, 1997; Wimalasiri, 1995), the mechanism of how these practices affect commitment is still not well or clearly uncovered. Guzzo and Noonan (1994) indicated that the interpretation of the HRM practices by the employees would affect their commitment.

Organizational commitment can be interpreted as the employee's long-term relationship and intention to stay in the workplace along with an unshakable belief in the goals and objectives of his/her organization, followed by a devoted effort to reach these goals (Steers, 1977; Mowday, Steers, \& Porter, 1979). Organizational commitment comprises three types: affective (the psychological feeling and attachment of an employee to stay in the workplace socially and organizationally), continuance (the cost-benefit evaluation of whether to stay or leave), and normative (the feeling of being obliged to stay in the organization because of moral factors) (Meyer \& Allen, 1997).

\subsection{Recognition practices and organizational commitment}

Monetary compensation is important, but not sufficient, to keep employees. Non-monetary recognition plays the same role as compensation does. Praise, appreciation, and positive feedback from managers and peers for a job well done is imperative to generate job satisfaction and commitment (Park, Erwin \& Knapp, 1997; Davies, 
2001).

Recognition is needed in the social and organizational environment as a motivational tool to bring about a good work outcome. In high professional jobs, recognition is considered as a main objective to maintaining the feeling of high involvement and being an important element of the organization (Agarwal \& Ferratt, 1999). Paré and Tremblay (2007) confirmed that recognition is positively related to continuance and affective commitment in their study which targeted 2,398 "Quebec members of the Canadian Information Processing Society (CIPS)".

H1a: Recognition is positively related to Affective Commitment

H1b: Recognition is positively related to Continuance Commitment

H1c: Recognition is positively related to Normative Commitment

\subsection{Practices of competence development and organizational commitment}

Investment by the organization in employee training is intended to send a commitment message to its employees that individual development is a valued goal of the organization (McElroy, 2001). The employee's commitment might be influenced more by the message HRM practices convey to the employee than by the practices themselves (Guzzo \& Noonan, 1994; Iles, Mabey \& Robertson, 1990). Training is used to enhance specific skills and correct performance issues to empower employees with the skills needed for the current and future job requirement (Gomez-Mejia, Balkin \& Cardy, 1995: Gold, 2001; Wood \& De Menezes, 1998).

Koys $(1988,1991)$ found that workers' commitment is related directly to their faith in the intention of the organization's HRM practices to keep skilled employees and treat them fairly. The employee's skill, training, and personal development practices, including job redesign/enrichment, have shown positive results in building the employee's confidence level, a sense of control, and identification of their work, therefore, a result of affective commitment (Meyer, Becker \& Vandenberghe, 2004).Building employees' skills to perform their job would establish a higher level of confidence as well as the employees' perception that the organization values their presence, therefore establishing employees' long-term commitment (Smith, 1995).

In addition to the positive link between commitment and profit sharing, bonuses, and pay, Landau and Hammer (1986) indicated that organizational commitment is enhanced by offering employees "advancement opportunities" within the organization. Organizational commitment also showed a positive link with the practices of profit sharing, bonuses, and pay.

H2a: Competence development is positively related to Affective Commitment

$\mathrm{H} 2 \mathrm{~b}$ : Competence development is positively related to Continuance Commitment

H2c: Competence development is positively related to Normative Commitment

\subsection{Fair rewards and organizational commitment}

Previous studies on the influence of human resource practices on organizational commitment revealed a causal relationship between rewards and benefits and commitment. Pay can be used as an incentive to boost employees' motivation and commitment to achieve organizational goals (Pfeffer, 1994, 1995, 1998).Many employees look at pay allocation with suspicion and as unfair practice among peers (Trevor, Gerhart \& Boudreau, 1997), which explains why the relationship between pay and commitment was found insignificant (Motowildo, 1988; Currall, Towler, Judge \& Kohn, 2005; Tekleab, Bartol\& Liu, 2005; Trevor et al., 1997).

When employees perceive, believe, and understand that the pay program intends to provide "internal pay equity", they tend to have high organizational commitment (Stum, 1999).

Attractive benefits packages are viewed by employees as a sign that the organization cares and supports its employees, resulting in the development of a strong affective commitment and the belief that the loss of such a package would be costly. This feeling results in a greater experience of a continuance commitment, indebted attachment to the workplace, leading in turn to a stronger normative commitment (Meyer \& Allen, 1997). More and more research revealed a positive link between benefit packages and employee commitment (Grover \& Crooker, 1995).

Reward practices would link employees' performance level to the expected rewards. Therefore, management should implement a "performance-contingent" reward system to predict an employee's output and performance commitment in the organization (Gagne' \& Deci, 2005). The equity theory suggested that employees weigh their effort (output) with the compensation they receive. If viewed as a fair package, employees see justice is being provided, become satisfied, and therefore commit with a long-term relationship in the organization (Adams, 1965). Multiple studies (Pillai, Schriesheim \& Williams, 1999; Folger \& Konovsky, 1989; Gopinath \& Becker, 
2000) have confirmed this relationship between fair compensation and organizational commitment.

H3a: Fair Rewards are positively related to Affective Commitment

H3b: Fair Rewards are positively related to Continuance Commitment

H3c: Fair Rewards are positively related to Normative Commitment

\subsection{Information sharing and organizational commitment}

Many researchers have identified a relationship between information sharing and organizational commitment for many years. Management adopts information sharing as an important and effective tool to enhance and strengthen the employee's commitment to the organization. The information sharing process involves the way the organization sends and receives knowledge among the organization members in order to strengthen the decision making process. This practice ensures that employees are being recognized as part of the decision making process and management are treating their views or opinions with respect.

Meyer and Allen (1997) reported that information sharing is positively correlated to affective commitment by building management-employee trust and workers' self-worthiness. Aligned with Meyer and Allen, Trombetta and Rogers (1988), Thornhill, Lewis and Saunders (1996), and Guzley (2001) confirmed this relationship, stating that open and transparent communication along with access to adequate information and participative decision making involvement build a positive affective commitment. On the other hand, fostering downward and upward flow of communication among different levels of the organization would influence the level of employee commitment and comfort in the workplace (Young \& Worchel, 1998).

Parker and Kyi (2006) and Postames, Tanis and De Wit (2001) shed light on what is called vertical and horizontal communication and information sharing. Vertical information flows from top management to employees at the lower level, while vertical information is about social communication. Both findings showed only vertical information sharing reveals a positive and significant association with organizational and performance commitment. By involving employees with this knowledge sharing, management would build a healthy environment in which employees gain self-confidence, recognition of their ideas, and a feeling of control over what they are doing; this would lead to mutual respect, which positively impacts the employees' level of commitment (Leana \& Florkowski, 1992; Pfeffer \& Veiga, 1999; Cook, 1994; Campbell, 2000). In the meantime, sharing information does not mean sacrificing trade secrets. Management has to decide what type and how much information to share with employees. Usually upper level management possesses more information than lower level employees. The organization would not share information if "it carries high efficiency cost" (Ronde, 2001).

H4a: Information sharing is positively related to Affective Commitment

$\mathrm{H} 4 \mathrm{~b}$ : Information sharing is positively related to Continuance Commitment

$\mathrm{H} 4 \mathrm{c}$ : Information sharing is positively related to Normative Commitment

\section{Methodology}

\subsection{Procedures}

A total of 1000 questionnaires were distributed to various levels of employees of the participant banks via the internal mail system through the HR manager. Each questionnaire included a covering letter explaining the aim of the study and its implications for the banking sector in Kuwait in terms of employees' commitment. For the purpose of maintaining confidentiality and anonymity, the completed questionnaires were returned to the HR manager via the internal mail system. In total, 460 employees responded, generating an overall usable response rate of $39.8 \%$ (62 non-usable responses).

\subsection{Participants and sample proportion}

The surveyed participants were permanent, full-time and part-time employees (managers and non-managers) of five large private banks in Kuwait: National Bank of Kuwait (NBK), Gulf Bank, Kuwait Finance House (KFH), Al-Ahly Bank of Kuwait (ABK), and the Bank of Kuwait and Middle East (BKME). Each bank has more than 500 employees. There was a fairly close split between male $(56.55 \%)$ and female $(43.5 \%)$ participants and a fair distribution among age groups (28\% between $21-25$ years, $52 \%$ between $26-35$ years, $13 \%$ between $36-45$ years, $5.5 \%$ between $46-55$ years, $0.9 \%$ between $56-60$ years and $0 \%$ over 65 years). The sample was relatively young in terms of age since the majority $(80 \%)$ was less than 35 -years-old. Regarding the educational level, the majority of respondents (86\%) held a diploma and higher degree. Furthermore, $48.3 \%$ of respondents had been in their position for five years and above, and $18.3 \%$ of respondents had been working in the present organization for over five years. In terms of positions, 262 respondents were non-managerial $(66 \%)$; the 
remaining respondents were managerial (34\%). Table 1 details the sample proportion with respect to gender, age, educational level, job tenure, and organizational tenure.

\subsection{Measures}

\subsubsection{Human Resource management practices}

The HR practices were measured with a scale for recognition, competence development, fair rewards, and information sharing. The intended outcomes included affective, continuance, and normative commitment.

Tremblay, Rondeau and Lemelin (1997) assessed all HR practices but one using a five-point likert scale ( $1=$ strongly disagree to $5=$ strongly agree), indicating the extent to which the four practices were used in their organization. The first HR practice, labeled 'recognition', included five items measuring the recognition of employees' suggestions and efforts from supervisors and peers (Cronbach alpha $=0.812$ ). The second HR practice, labeled 'competence development', included six items measuring employees' development skills and their chances for promotion (Cronbach alpha $=0.855$ ). The third HR practice, labeled 'fair rewards', included five items measuring employees' perception of their compensation level (Cronbach alpha $=0.811$ ). The last HR practice, labeled 'information sharing', adopted from a survey done by Lawler, Mohrman and Ledford (1992), included six items measuring employees' involvement in the company's decision making process at all levels. The resulting Cronbach alpha for information sharing was 0.879 .

\subsubsection{Organizational commitment}

The three dimensions of the employee organizational commitment were assessed using the scale developed by Meyer, Allen and Smith (1993). The affective commitment scale included seven items measuring the emotional reasons for which employees would stay in the organization. The resulting Cronbach alpha for affective commitment is 0.678 . The continuance commitment scale included seven items measuring the economic reasons for which employees would stay in the organization. The resulting Cronbach alpha for continuance commitment is 0.750 . The normative commitment scale included five items measuring the ethical and the moral reasons for which employees would stay in the organization. The resulting Cronbach alpha for normative commitment is 0.526 .

\subsection{Factor analysis}

For the purpose of data reduction, in order to create smaller summary variables sets and to construct a base understanding of the conceptual framework of the HRM practices-commitment phenomena, exploratory factor analysis has been conducted in this study. We used two criteria for determining the appropriateness of the factor model: Eigenvalue (1.00) and communality $(0.20)$. Based on the assumption that the factors are correlated, we used the direct oblique rotation to rotate the factor matrices to simple structure. The results of factor analyses (HRM practices), Cronbach's alpha, and the total explained variance are presented in Table 2.

Another set of exploratory factor analyses has been used for the three dimensions of organizational commitment, excluding all factors loading less than 0.35 . As it is often the case for all measures, we used the direct oblique rotation since the components of commitment have been found correlated (Meyer, Stanley, Herscovitch \& Topolnytsky, 2002).

The data in Table 3 reveals that the commitment scales possess quite acceptable psychometrical properties. All factors account for a passable proportion of the variance in the variables and the reliability coefficients suggested a reasonable degree of internal consistency for each scale. Also, the three factors appear to be correlated.

These results support Allen and Meyer's (1990) findings that affective, continuance, and normative commitment are conceptually and empirically separable components of organizational commitment.

\section{Results}

Table 4 shows the three subscale items of commitment, Cronbach's alpha and the total explained variance, omitting factors loading less than .035. A series of hierarchical regression analyses were conducted to examine the impact of human resource practices on affective, continuance and normative commitment (see Tables 5, 6, and 7). The variables were entered into the regression equation in two steps. The control variables were entered first. The HR practices were entered second.

The first set of regression analyses was conducted with affective commitment as the dependent variable. The results provide support for the Hypotheses: H2a, H3a and H4a. (Overall model: $\mathrm{F}=27.301, \mathrm{P}<.001$; adjusted $\mathrm{R}$-square $=.291$.) As expected, competence development, fair rewards, and information sharing were positively and significantly related to affective commitment $(\mathrm{B}=.10, \mathrm{P}<.05 ; \mathrm{B}=.21, \mathrm{P}<.001 ;$ and $\mathrm{B}=.10, \mathrm{P}<.05)$. In conflict with previous studies, the relationship between recognition and affective commitment (H1a) was found to be 
positive but did not exhibit a statistical significance. The results of these analyses are presented in Table 5 .

The overall model was significant when continuance commitment was entered as the dependent variable. The results provide support for the hypotheses $\mathrm{H} 3 \mathrm{~b}$ and $\mathrm{H} 4 \mathrm{~b}$. (Overall Model: $\mathrm{F}=5.688, \mathrm{P}<.001$; adjusted $\mathrm{R}$-square $=.068$.) The relationships between continuance commitment and fair rewards and information sharing were significant $(\mathrm{B}=.11, \mathrm{p}<.05 ; \mathrm{B}=.18, \mathrm{P}<.001)$. However, hypotheses $\mathrm{H} 1 \mathrm{~b}$ and $\mathrm{H} 2 \mathrm{~b}$ were not supported. No significant relationships were found between continuance commitment and both recognition and competence development. The results of these analyses are presented in Table 6 .

Also, the overall model was significant when normative commitment was entered as the dependent variable $(\mathrm{F}=9.346, \mathrm{P}<.001$; adjusted $\mathrm{R}$-square=.086). Information sharing was positively related to normative commitment $(\mathrm{H} 4 \mathrm{c})(\mathrm{B}=.025, \mathrm{p}<.001)$. Hypotheses $\mathrm{H} 1 \mathrm{c}, \mathrm{H} 2 \mathrm{c}$, and $\mathrm{H} 3 \mathrm{c}$ were not supported. In conflict with previous studies, the relationships between normative commitment and recognition, competence development and fair rewards were found to be negative and not significant $(\mathrm{B}=-.012$ for recognition; $\mathrm{B}=-.009$ for competence development and $\mathrm{B}=-.049$ for fair rewards). The results of these analyses are presented in Table 7.

\section{Discussion, limitation, and implication of the study}

The primary purpose of this study was to evaluate the impact of several HR practices on employees' organizational commitment in the banking sector of Kuwait. We hypothesized that the following practices were related to organizational commitment: (1) recognition; (2) competence development; (3) fair rewards; and (4) information sharing.

For the affective commitment, apart from hypothesis H1a, all other hypotheses were confirmed. For the continuance commitment, apart from hypotheses $\mathrm{H} 1 \mathrm{~b}$ and $\mathrm{H} 2 \mathrm{~b}$, all other hypotheses were confirmed. The only hypothesis related to normative commitment that was confirmed is $\mathrm{H} 4 \mathrm{c}$ on the impact of information sharing; all other hypotheses were not confirmed.

As can be noticed from Table 5, the affective component of organizational commitment of Kuwaiti employees depends on the competence development practices, on information sharing, and on fair rewards. Competence development practices are all activities which invest in human capital and provide employees with the needed resources and opportunities to improve and develop their skills, enabling them to work in an environment that promotes career development and initiative-taking. Commitment and intention to stay in the organization occur when HR practices produce in them a feeling of autonomy and competence (Meyer \& Herscovitch, 2001; Meyer et al., 2004). In this sense, the results of this study confirm the findings of previous research (Barnard \& Rodgers, 2000).

Results supported the hypothesis that fair rewards are positively related to affective commitment. The Mercer report (2003) demonstrated that employees who are rewarded fairly will be more committed and stay (I estimated my salary as being fair internally). Companies that use the reward budget effectively to distribute the rewards adequately among top performers receive an increased consideration than other companies (The pay increases and/or bonuses I received in the last two years adequately reflect my recent performance evaluations).

Information sharing practices include all organizational practices implemented to transmit and receive information, and therefore to support decision-making. We found that the information sharing practices are more likely to significantly increase the emotional attachment of employees to the organization (affective commitment). Nevertheless, many companies would worry about sharing critical information (employees are regularly informed of financial results) with their employees because of the possibility of losing control of them (Pfeffer \& Veiga, 1999).

Surprisingly and contrary to our expectations, our study failed to find a significant relationship between recognition and affective commitment. Recognition practices involve all activities that allow managers to recognize their subordinates' contributions. According to the social exchange theory (Whitener, 2001), employees excel at work when their supervisors provide them with positive considerations. The non-significant association between recognition and affective commitment could be due to the individualism/collectivism cultural dimensions of Geert Hofstede's work. Kuwait is classified as a collectivist culture, high in power distance, and high in uncertainty avoidance. In contrast to individualistic societies, in this culture work performance is evaluated based on a group or teamwork, not on an individual basis (Carrol \& Gannon, 1997). Therefore, recognition for the banking sector employees tends not to pay personal/individualistic attention to their solo performance.

However, we speculated that HRM practices might also affect continuance commitment by making it costly for employees to leave (e.g., chances for promotion and efforts recognition would be lost). The results show that 
only fair rewards and information sharing were significantly associated with continuance commitment; recognition and competence development were not. This could be due to the fact that the majority of employees in the banking sector of Kuwait are expats, and are likely to be committed to their organization not only emotionally but also because of the dollar value of their job. Our findings are not consistent with the human capital theory (Becker, 1975), which dictates that employees stay because of the fewer opportunities they have elsewhere due to the difficulties in exporting the acquired knowledge outside the company. This could also be due to the mismatch between recognition and competence development and the economic value of the job where the equity theory is not respected since the Kuwaiti employees are much more compensated regardless of their competences than non-Kuwaiti employees performing the same job.

The HRM practices did not contribute significantly to the prediction of the normative commitment, either individually or as a group, except for hypothesis H4c. Of the HRM practices measured in this research, information sharing practices were found to be significantly related to normative commitment. This relationship could be explained in the context of the social values system held by employees from the Middle East in general and the Kuwaitis in particular. Employees feel morally and ethically committed to stay within the same organization based on employees-management personal relationships within a high context environment. They tend to develop social memberships around the workplace so that leaving the organization for materialistic endeavor somewhere else is considered morally unacceptable among their peers.

Our study shows that the obligation to remain in the organization (normative commitment) is developed independently of desire. Again, due to the fact that expat employees are working in Kuwait for the purpose of maximizing their profit, the psychological contract between employers and employees is violated; there is then no obligation on the part of employees to reciprocate.

Several limitations in this study should be taken into consideration; firstly, our sample is mainly based on a specific Middle Eastern country, Kuwait, which explains why some hypotheses have been rejected because of cultural differences between the countries mentioned in our literature review and the sample country. Secondly, this study has investigated only one industry, the banking sector, which may have limitations for generalization to other sectors of the economy and vice versa. Thirdly, only four HR practices were investigated in this study. There are probably other HR practices that have a significant impact on the level of employee commitment and which are not taken into consideration in this research (organizational support, decentralization, selective hiring, job security...).

Further research could clarify the causal relationship between HR practices and organizational commitment. Much of the research on HR practices has been conducted in Western societies; thus, the findings of this study can be useful in future comparative studies. Another direction for future research is to examine HR practices and organization commitment in sets, not as separate components, in order to assess their collective effect.

\section{References}

Adams, J. (1965). Inequity in social exchange. In L. Berkowitz (Ed.), Advance in Experimental Social Psychology (2nd ed.) (pp. 267-99). New York: Academic Press.

Agarwal, R., \& Ferratt, T. W. (1999). Coping with labor scarcity in IT: Strategies and practices for effective recruitment and retention. Cincinnati, $\mathrm{OH}$ : Pinnaflex.

Allen, N. J., \& Meyer, J. P. (1990). The measurement and antecedents of affective, continuance, and normative commitment to the organization. Journal of Occupational Psychology, 63, 1-18.

Barnard, M. E., \& Rodgers, R. A. (2000). How are internally oriented HRM policies related to high-performance work practices? Evidence from Singapore. The International Journal of Human Resource Management, 11, 1017-46.

Beck, K., \& Wilson, C. (2001). Have we studied, should we study, and can we study the development of commitment? Methodological issues and the developmental study of work-related commitment. Human Resource Management Review, 11, 257-278.

Becker, G. (1975). Human Capital. New York: National Bureau of Economics Research.

Campbell, D. J. (2000). The Proactive Employee. Academy of Management Executive, 14(3), 52-66.

Carrol, S. J., \& Gannon, M. J. (1997). Ethical dimensions of international management. Thousand Oaks, CA: Sage Publications.

Cohen, A. (1999). Relationships among five forms of commitment: An empirical assessment. Journal of Organizational Behavior, 20(3), 285-308. 
Cook, W. (1994). Employee participation programs, group-based incentives, and company performance: A union-non-union comparison. Industrial and Labor Relations Review, 47(4), 594-609.

Currall, S. C., Towler, A. J., Judge, T. A., \& Kohn, L. (2005). Pay satisfaction and organizational outcomes. Personnel Psychology, 58, 613-640.

Davies, R. (2001). How to boost staff retention. People Management, 7, 54-6.

DeCotiis, T., \& Summers, T. (1987). A path analysis of a model of the antecedents and consequences of organizational commitment. Human Relations, 40(7), 445-70.

Delaney, J., \& Huselid, M. (1996). The impact of human resource management practices on perceptions of organizational performance. The Academy of Management Journal, 39(4), 949-969.

Folger, R., \& Konovsky, M. A. (1989). Effects of procedural and distributive justice on reactions to pay raise decisions. Academy of Management Journal, 32, 115-130.

Gagné, M., \& Deci, E. L. (2005). Self-determination theory and work motivation. Journal of Organizational Behavior, 26, 331-362.

Gold, M. (2001). Breaking all the rules for recruitment and retention. Journal of Career Planning \& Employment, 61(3), 6-8.

Gomez-Mejia, L. R., Balkin, D. B., \& Cardy, R. L. (1995). Managing Human Resources. Englewood Cliffs, NJ: Prentice-Hall, Inc.

Gopinath, C., \& Becker, T. E. (2000). Communication, procedural justice, and employee attitudes: Relationships under conditions of divestiture. Journal of Management, 26(1), 63-83.

Grover, S., \& Crooker, K. (1995). Who appreciates family-responsive human practices: The impact of family-friendly practices on the organizational attachment of parents and nonparents. Personnel Psychology, 48, 271-288.

Guzley, R. M. (2001). Organizational climate and communication climate: Predictors of commitment to the organization. Management Communication Quarterly, 5(4), 379-402.

Guzzo, R., \& Noonan, K. (1994). Human resource practices as communications and the psychological contract. Human Resource Management, 33(3), 447-462.

Hofstede, G. (1991). Cultures and organizations. Berkshire, Europe: McGraw-Hill.

Howkins, W. D. (1998). Predictors of affective organizational commitment among high school principals (Doctoral dissertation, Virginia Polytechnic Institute and State University). [Online] Avaialble: http://scholar.lib.vt.edu/theses/available/etd-32298-1310/unrestricted/DISSERTATION.PDF

Igbaria, M., \& Wormley, W. M. (1992). Organizational experiences and career success of MIS professionals and managers: An examination of race differences. MIS Quarterly, 16 (4), 507-29.

Iles, P., Mabey, C., \& Robertson, I. (1990). HRM Practices and employee commitment: Possibilities, pitfalls and paradoxes. British Journal of Management, 1(3), 147-157.

Kaldenberg, D. O., Becker, B. W., \& Zvonkovic, A. (1995). Work and commitment among young professionals: A study of male and female dentists. Human Relations (HR), 48(11), 1355-77.

Knoke, D. (1988). Incentives in collective action organizations. American Sociological Review, 53 (3), 311-29.

Koys, D. J. (1988). Human resource management and a culture of respect: Effects of employees' organizational commitment. Employee Rights and Responsibilities Journal, 1, 57-68.

Koys, D. J. (1991). Fairness, legal compliance, and organizational commitment. EmployeeRights and Responsibilities Journal, 4(4), 283-291.

Landau, J., \& Hammer, T. H. (1986). Clerical employees' perceptions of intraorganizational career opportunities.Academy of Management Journal, 29, 385-404.

Lawler, E. E., Morhman, S. A., \& Ledford, G. E. (1992). Practices and results in Fortune 1000 companies. Employee involvement and TQM (pp. 9-40). San Francisco, CA: Jossey-Bass Publishers.

Leana, C. R., \& Florkowski, G. W. (1992). Employee involvement programs: Integrating psychological theory and management practice. In G. Ferris (Ed.), Research in Personnel and Human Resources Management, 10, Greenwich, CT: JAI Press. 
Liou, K-T., \& Nyhan, R. (1994). Dimensions of organizational commitment in the public sector: An empirical assessment. Public Administration Quarterly, 18(1), 99-118.

Mathieu, J. E., \& Zajac, D. M. (1990). A review and meta-analysis of the antecedents, correlates, and consequences of organizational commitment. Psychological Bulletin, 108, 171-194.

Mayer, R.C., \& Schoorman, F. D. (1998). Differentiating antecedents of organizational commitment: A test of March and Simon's model. Journal of Organizational Behavior, 19(1), 15-28.

McElroy, J. (2001). Managing workplace commitment by putting people first.Human Resource Management Review, 11(3), 327-335.

Mercer Report. (2003). Mercer study raises red flags for employer pay and benefit plans (findings of the 2002 people at work survey). Human Resource Department Management Report, May, pp. 23-15.

Meyer, J. P., \& Allen, N. J. (1997). Commitment in the workplace: Theory, research, and application. Thousand Oaks, CA: Sage.

Meyer, J. P., \& Herscovitch, L. (2001). Commitment in the workplace: Toward general model. Human Resource Management Review, 11, 299-326.

Meyer, J. P., Allen, N. J., \& Smith, C. A. (1993). Commitment to organizations and occupations: Extension and test of a three-component conceptualization. Journal of Applied Psychology, 78, 538-552.

Meyer, J. P., Becker, T. E., \& Vandenberghe, C. (2004). Employee motivation and commitment: A conceptual analysis and integrative model. Journal of Applied Psychology, 89, 991-1007.

Meyer, J. P., Stanley, D. J., Herscovitch, L., \& Topolnytsky, L. (2002). Affective, continuance, and normative commitment to the organization: A meta-analysis of antecedents, correlates, and consequences. Journal of Vocational Behavior, 61(1), 20-52.

Motowildo, S.J. (1988). Predicting sales turnover from pay satisfaction and expectation. Journal of Applied Psychology, 68, 484-489.

Mowday, R. T., Steers, R. M., \& Porter, L. W. (1979). The measurement of organizational commitment. Journal of Vocational Behavior, 14, 224-247.

Paré, G., \& Tremblay, M. (2007). The influence of high-involvement human resources practices, procedural justice, organizational commitment, and citizenship behaviors on information technology professionals' turnover intentions. Group \& Organization Management, 32(3), 326-357.

Park, R., Erwin, P. J., \& Knapp, K. (1997). Teams in Australia's automotive industry: Characteristics and future challenges. International Journal of Human Resource Management, 8, 780-96.

Parker, R., \& Kyi, L. (2006). Vertical information sharing in the budgeting process. Accounting. Organizations and Society, 31(1), 27-45.

Paul, A. K., \& Anantharaman, R. N. (2004). Influence of HRM practices on organizational commitment: A study among software professionals in India. Human Resource Development Quarterly, 15(1), 77-88.

Pfeffer, J. (1994). Competitive advantage through people: Unleashing the power of the workforce. Boston, CA: Harvard Business School Press.

Pfeffer, J. (1995). Producing sustainable advantage through the effective management of people. Academy of Management Executive, 9(1), 55-69.

Pfeffer, J. (1998). The human equation: Building profits by putting people first. Boston, Massachusetts: Harvard Business School Press.

Pfeffer, J., \& Veiga, J. F. (1999). Putting people first for organizational success. Academy of Management Executive, 13, 37-48.

Pillai, R., Schriesheim, C., \& Williams, E. (1999). Fairness perceptions and trust as mediators for transformational and transactional leadership: A two-sample study. Journal of Management, 25(6), 897.

Porter, Lyman W., Richard M. Steers, Robert T. Mowday and Paul v. Boulian. Organizational Commitment, Job Satisfaction, and Turnover among Psychiatric Technicians. Journal of Applied Psychology, 59(5), 603-609.

Postames, T., Tanis, M., \& De Wit, B. (2001). Communication and commitment in organizations: A social identity approach. Group Process and Intergroup Relations, 4(3), 227-246.

Ronde, T. (2001). Trade secrets and information sharing. Journal of Economics and Management Strategy, 10(3), 
391-417.

Scarpello, V., Ledvinka, J., \& Bergmann, T. (1995). Human resource management: Environments and functions (2nd ed.). Cincinnati, OH: Southwestern College Publishing.

Smith, C. A. (1995). Human resource practices and policies as antecedents of organizational commitment. $\mathrm{PhD}$ dissertation, Western University.

Steers, R. (1977). Antecedents and outcomes of organizational commitment. Administrative Science Quarterly, 22(1) (Mar. 1977), 46-56.

Stum, D. L. (1999). Maslow revisited: Building the employee commitment pyramid. Strategy and Leadership, 29(4), 4-9.

Tekleab, A. G., Bartol, K. M., \& Liu, W. (2005). Is it pay levels or pay raises that matter to fairness and turnover? Journal of Organizational Behavior, 26, 899-921.

Thornhill, A., Lewis, P., \& Saunders, M. N. K. (1996). The role of employee communication in achieving commitment and quality in higher education. Quality Assurance in Education, 4(1).

Tremblay, M., Rondeau, A., \& Lemelin, M. (1997). La Mise en Oeuvre de PratiquesInnovatrices de Gestion des RessourcesHumaines a-t-elleune Influence surla Mobilisation, GRH face a la crise: GRH en crise? [Does the implementation of the innovative HR practices have an influence on mobilization? Human resource management in face of the crisis: Is Human resource management in crisis?]. (pp. 97-109). Montreal: Presses HEC.

Trevor, C. O., Gerhart, B., \& Boudreau, J. W. (1997). Voluntary turnover and job performance: Curvilinearity and the moderating influences of salary growth and promotions. Journal of Applied Psychology, 82(1), 44-61.

Trombetta, J. J., \& Rogers, D. P. (1988). Communication climate, job satisfaction, and organizational commitment: The effect of information adequacy, communication openness and decision participation. Management Communication Quarterly, 1(14), 494-514.

Ulrich, D. (1997). Measuring human resources: An overview of practice and a prescription of results. Human Resources Management, 36, 303-320.

Van Dyne, L., \& Ang, S. (1998). Organizational citizenship behavior of contingent workers in Singapore. Academy of Management Journal, 41(6), 692-703.

Whitener, E. M. (2001). Do "high commitment" human resource practices affect employee commitment? A cross-level analysis using hierarchical linear modeling. Journal of Management, 27, 515-35.

Wimalasiri, J. S. (1995). An examination of the influence of human resource practices, organizational commitment and job satisfaction on work performance. International Journal of Management, 12(3), 353-363.

Wood, S., \& DeMenezes, L. (1998). High commitment management in the UK: Evidence from the workplace industrial welationswurvey, and employers' manpower and skills practice survey'. Human Relations, 51(4), 485-515.

Young, B. S., \& Worchel, S. (1998). Organizational commitment among public service employees. Public Personnel Management, 27(3), 339-349 
Table 1. Sample frequencies

\begin{tabular}{|l|c|l|l|c|}
\hline Variables & Sample $(\mathrm{n}=398)$ & & Variables & Sample $(\mathrm{n}=398)$ \\
\hline Gender & & & Job Tenure & \\
\hline Male & 56.5 & & $0-5$ & 51.7 \\
\hline Female & 43.5 & & $6-10$ & 37.11 \\
\hline Age & & & Above 10 & 11.19 \\
\hline $21-25$ & 28.4 & & Org. Tenure & \\
\hline $26-35$ & 52.2 & & $0-5$ & 81.7 \\
\hline $36-45$ & 13 & & $6-10$ & 13.42 \\
\hline $46-55$ & 5.5 & & Above 10 & 4.88 \\
\hline $56-60$ & 9 & & Position level & \\
\hline above 65 & 0 & & Manager & 34 \\
\hline Edu. Level & & & Non-Manager & 66 \\
\hline HS & 12.6 & & & \\
\hline Diploma & 14.4 & & & \\
\hline Degree & 71.7 & & & \\
\hline Post Grad. & 1.3 & & & \\
\hline
\end{tabular}


Table 2. Exploratory factor analysis for HR practices

\begin{tabular}{|c|c|c|c|c|c|}
\hline & 1 & 2 & 3 & 4 & $\begin{array}{c}\text { Cronbach's } \\
\text { Alpha }\end{array}$ \\
\hline Recognition practices & & & & & 0.812 \\
\hline $\begin{array}{l}\text { 1. Employees'suggestions are seriously taken into } \\
\text { consideration }\end{array}$ & 0.69 & & & & \\
\hline $\begin{array}{l}\text { 2. In my work unit, employees' suggestions are followed } \\
\text { up regularly }\end{array}$ & 0.63 & & & & \\
\hline $\begin{array}{l}\text { 3. When an employee does good quality work, his } \\
\text { colleagues regularly show him their appreciation. }\end{array}$ & 0.59 & & & & \\
\hline $\begin{array}{l}\text { 4. In my work unit, supervisors tangibly recognize } \\
\text { employees' efforts (e.g. giving tickets to cultural or sports } \\
\text { events, dinners at restaurants) }\end{array}$ & 0.73 & & & & \\
\hline $\begin{array}{l}\text { 5. In my work unit, employees receive written recognition } \\
\text { from their supervisors.(e.g. memos) unit, supervisors } \\
\text { regularly }\end{array}$ & 0.66 & & & & \\
\hline Competence development practices & & & & & 0.855 \\
\hline $\begin{array}{l}\text { 1. Employees can develop their skills in order to increase } \\
\text { their chances of being promoted }\end{array}$ & & 0.7 & & & \\
\hline 2. Employees can rotate jobs to develop their skills & & 0.68 & & & \\
\hline $\begin{array}{l}\text { 3. Several professional development activities (e.g. } \\
\text { coaching, training) are offered to employees to improve } \\
\text { their skills and knowledge. }\end{array}$ & & 0.7 & & & \\
\hline $\begin{array}{l}\text { 4. Proficiency courses such as specialized technical } \\
\text { courses and professional certification are encouraged by } \\
\text { management }\end{array}$ & & 0.66 & & & \\
\hline 5. I am able to apply new skills in my work & & 0.68 & & & \\
\hline $\begin{array}{l}\text { 6. Managers encourage employees to apply their new } \\
\text { abilities and skills in the context of their daily work }\end{array}$ & & 0.58 & & & \\
\hline Fair rewards practices & & & & & 0.811 \\
\hline 1. I estimate my salary as being fair internally & & & 0.84 & & \\
\hline $\begin{array}{l}\text { 2. My salary is fair in comparison with what is offered for } \\
\text { a similar job elsewhere }\end{array}$ & & & 0.87 & & \\
\hline $\begin{array}{l}\text { 3. In my work unit, our supervisors assign mandates in a } \\
\text { fair manner }\end{array}$ & & & 0.58 & & \\
\hline $\begin{array}{l}\text { 4. In my work unit, employees consider that their } \\
\text { compensation level adequately reflects their level of } \\
\text { responsibility in the organization }\end{array}$ & & & 0.47 & & \\
\hline $\begin{array}{l}\text { 5. The pay increases and/or bonuses I received in the last } \\
\text { two years adequately reflect my recent performance } \\
\text { evaluations }\end{array}$ & & & 0.7 & & \\
\hline Information sharing practices & & & & & 0.879 \\
\hline $\begin{array}{l}\text { 1. Employees are regularly informed of future bank } \\
\text { projects (e.g. major investments, acquisitions, new } \\
\text { technologies...) }\end{array}$ & & & & 0.69 & \\
\hline 2. Employees are regularly informed of financial results & & & & 0.75 & \\
\hline $\begin{array}{l}\text { 3. Employees are regularly informed of their work unit's } \\
\text { performance }\end{array}$ & & & & 0.76 & \\
\hline $\begin{array}{l}\text { 4. Employees are regularly informed of technological } \\
\text { orientations }\end{array}$ & & & & 0.82 & \\
\hline $\begin{array}{l}\text { 5. Managers regularly inform employees of the level of } \\
\text { customer satisfaction for products or services offered }\end{array}$ & & & & 0.71 & \\
\hline $\begin{array}{l}\text { 6. Employees' suggestions concerning ways to improve } \\
\text { our work unit's effectiveness are seriously taken into } \\
\text { account. }\end{array}$ & & & & 0.48 & \\
\hline Total explained variance: $\mathbf{6 0 . 7 2 8 \%}$ & $16.88 \%$ & $15.98 \%$ & $14.91 \%$ & $12.96 \%$ & \\
\hline
\end{tabular}

Note. Extraction Method: Principal Component Analysis; Rotation Method: Oblimin with Kaiser Normalization;* Factor loading less than 0.35 are not reported 
Table 3. Exploratory factor analysis for Organizational Commitment

\begin{tabular}{|c|c|c|c|c|}
\hline & 1 & 2 & 3 & $\begin{array}{l}\text { Cronbach's } \\
\text { Alpha }\end{array}$ \\
\hline Affective Commitment & & & & .678 \\
\hline $\begin{array}{l}\text { 1- I would be very happy to spend the rest of my career with } \\
\text { this organization }\end{array}$ & .813 & & & \\
\hline 2- I really feel as if this organization's problems are my own & .835 & & & \\
\hline $\begin{array}{l}\text { 3- This organization has a great deal of personal meaning for } \\
\text { me }\end{array}$ & .810 & & & \\
\hline $\begin{array}{l}\text { 4- I do not feel a strong sense of belonging to my } \\
\text { organization }\end{array}$ & .000 & & & \\
\hline $\begin{array}{l}\text { 5- Even if it were to my advantage, I do not feel I would be } \\
\text { right to leave my organization }\end{array}$ & .648 & & & \\
\hline 6- I would feel guilty if I left my organization now & .576 & & & \\
\hline 7- This organization deserves my loyalty & .607 & & & \\
\hline Continuance Commitment & & & & .750 \\
\hline $\begin{array}{l}\text { 1- It would be very hard for me to leave my organization } \\
\text { right now even if I wanted to }\end{array}$ & & .593 & & \\
\hline $\begin{array}{l}\text { 2- Too much in my life would be disrupted if I decided I } \\
\text { wanted to leave my organization now }\end{array}$ & & .721 & & \\
\hline $\begin{array}{l}\text { 3- Right now, staying with my organization is a matter of } \\
\text { necessity as much as desire }\end{array}$ & & .759 & & \\
\hline $\begin{array}{l}\text { 4- I believe that I have too many options to consider leaving } \\
\text { this organization }\end{array}$ & & .365 & & \\
\hline $\begin{array}{l}\text { 5- One of the few negative consequences of leaving this } \\
\text { organization would be the scarcity of available job } \\
\text { alternatives }\end{array}$ & & .616 & & \\
\hline $\begin{array}{l}\text { 6- One of the major reasons I continue to work for this } \\
\text { organization is that leaving would require considerable } \\
\text { personal sacrifice- another organization may not match the } \\
\text { overall benefits I have here }\end{array}$ & & .745 & & \\
\hline $\begin{array}{l}\text { 7- If I had not already put so much of myself into this } \\
\text { organization I might consider working elsewhere }\end{array}$ & & .000 & & \\
\hline Normative Commitment & & & & .526 \\
\hline $\begin{array}{l}\text { 1- If I got another offer for a better job elsewhere, I would } \\
\text { not feel it was right to leave my organization }\end{array}$ & & & .000 & \\
\hline $\begin{array}{l}\text { 2- I was taught to believe in the value of remaining loyal to } \\
\text { one organization }\end{array}$ & & & .371 & \\
\hline $\begin{array}{l}\text { 3- Things were better in the days when people stayed with } \\
\text { one organization for most of their career }\end{array}$ & & & .463 & \\
\hline $\begin{array}{l}\text { 4- I do not think that wanting to be a "company man" or } \\
\text { "company woman" is sensible anymore }\end{array}$ & & & .657 & \\
\hline $\begin{array}{l}\text { 5- Employees generally move from organization to } \\
\text { organization too often }\end{array}$ & & & .603 & \\
\hline Total explained variance: $60.143 \%$ & $28.57 \%$ & $11.20 \%$ & $7.839 \%$ & \\
\hline
\end{tabular}

Extraction Method: Principal Component Analysis; Rotation Method: Oblimin with Kaiser Normalization; * Factor loading less than 0.35 are not reported 
Table 4. Means, Standard Deviations, Reliabilities and Correlations ( $\mathrm{N}=340)$

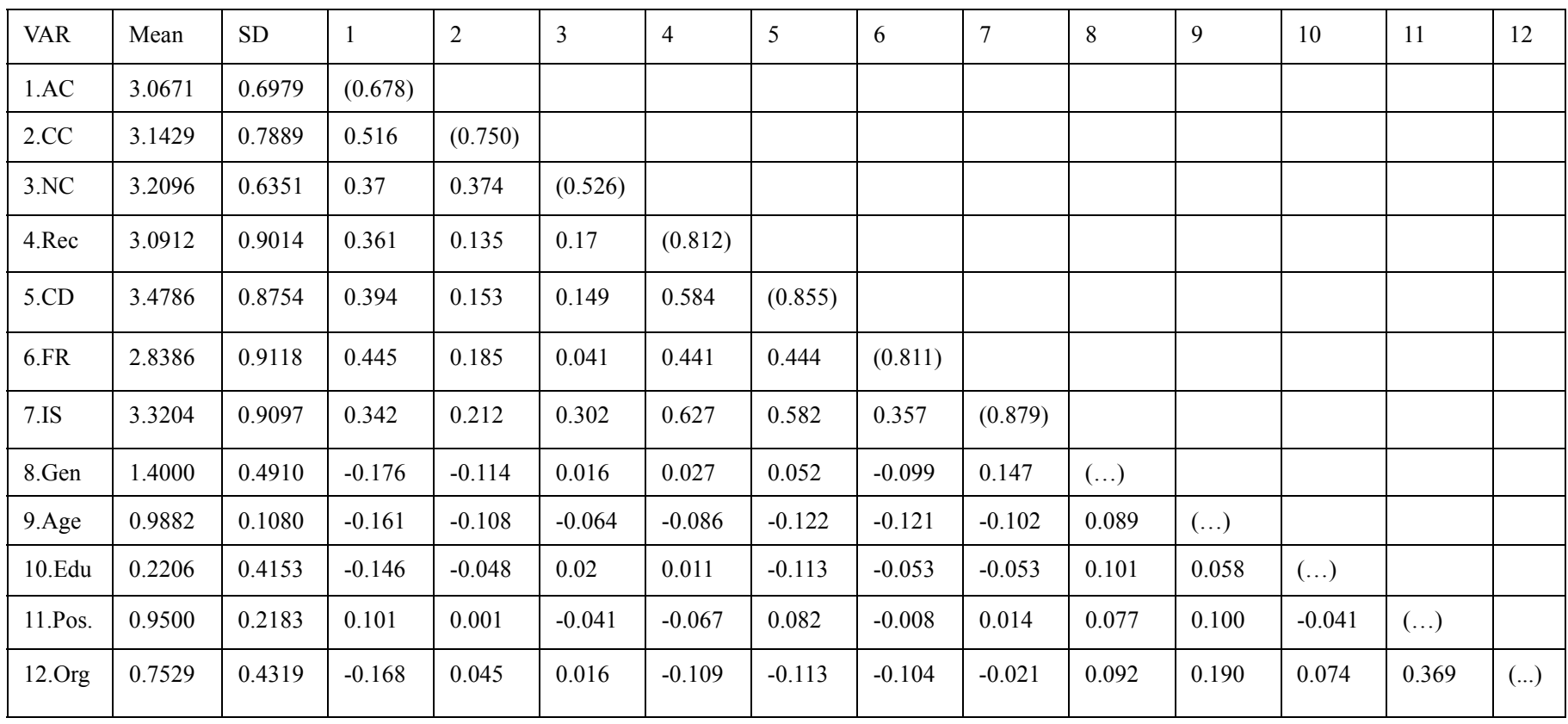

Note. $\mathrm{AC}=$ Affective Commitment; $\mathrm{CC}=$ Continuance Commitment; $\mathrm{NC}=$ Normative Commitment; Rec=Recognition; $\mathrm{CD}=\mathrm{Competence} \mathrm{Development;}$ FR=Fair Rewards; IS=Information Sharing; Gen=Gender; Edu=Educational Level; Pos= Positional Tenure; Org=Organizational Tenure Cronbach $\alpha$ coefficients appear in parentheses

Table 5. Results of the Hierarchical Regression Analyses for Human Resource Practices on Affective Commitment

\begin{tabular}{|c|c|c|c|c|c|c|c|c|}
\hline $\begin{array}{l}\text { Independent } \\
\text { variables }\end{array}$ & $\begin{array}{c}\text { Unstandardized } \\
\beta\end{array}$ & $\begin{array}{l}\text { Standard } \\
\text { error }\end{array}$ & $\begin{array}{c}\text { Standardized } \\
\beta\end{array}$ & R Square & $\begin{array}{l}\text { Adjusted } \\
\text { R Square }\end{array}$ & $\begin{array}{l}\text { R Square } \\
\text { Change }\end{array}$ & F change & $\begin{array}{l}\text { Sig.F } \\
\text { change }\end{array}$ \\
\hline Model1 & & & & .083 & .067 & .083 & 5.036 & .000 \\
\hline Gen & -.200 & .076 & -.140 & & & & & \\
\hline Age & -.760 & .358 & -.118 & & & & & \\
\hline Org & -.169 & .118 & -.104 & & & & & \\
\hline Model2 & & & & .312 & .291 & .228 & 27.301 & .000 \\
\hline Gen & -.225 & .068 & -.158 & & & & & \\
\hline Org & -.171 & .103 & -.106 & & & & & \\
\hline Rec & .046 & .050 & .059 & & & & & \\
\hline $\mathrm{CD}$ & .107 & .050 & $.135^{*}$ & & & & & \\
\hline FR & .216 & .041 & $.283^{* * *}$ & & & & & \\
\hline IS & .107 & .049 & $.139 *$ & & & & & \\
\hline
\end{tabular}

Notes: $* \mathrm{p}<.05 ; * * \mathrm{p}<.01 ; * * * \mathrm{p}<.001$

Gen=Gender; Edu=Educational Level; Pos= Positional Tenure; Org=Organizational Tenure; Rec=Recognition;

$\mathrm{CD}=$ Competence Development $\quad \mathrm{FR}=$ Fair Rewards; IS=Information Sharing 
Table 6. Results of the Hierarchical Regression Analyses for Human Resource Practices on Continuance Commitment

\begin{tabular}{|l|c|c|c|c|c|l|l|l|}
\hline $\begin{array}{l}\text { Independent } \\
\text { variables }\end{array}$ & $\begin{array}{c}\text { Unstandardized } \\
\beta\end{array}$ & $\begin{array}{c}\text { Standard } \\
\text { error }\end{array}$ & $\begin{array}{c}\text { Standardized } \\
\beta\end{array}$ & R Square & $\begin{array}{l}\text { Adjusted } \\
\text { R Square }\end{array}$ & $\begin{array}{l}\text { R Square } \\
\text { Change }\end{array}$ & F change & $\begin{array}{l}\text { Sig.F } \\
\text { change }\end{array}$ \\
\hline Model1 & & & & .033 & .015 & .033 & 1.884 & .083 \\
\hline Gen & -.179 & .088 & -.112 & & & & & \\
\hline Age & -.700 & .416 & -.096 & & & & & \\
\hline Edu & -.069 & .104 & -.036 & & & & & \\
\hline Pos & -.097 & .217 & -.027 & & & & & \\
\hline Org & .064 & .136 & .035 & & & & & \\
\hline Model2 & & & & .095 & .068 & .063 & 5.688 & .000 \\
\hline Gen & -.219 & .088 & -.136 & & & & & \\
\hline Age & -.403 & .410 & -.055 & & & & & \\
\hline Edu & -.034 & .102 & -.018 & & & & & \\
\hline Pos & -.157 & .212 & -.043 & & & & & \\
\hline Org & .041 & .134 & .022 & & & & & \\
\hline Rec & -.047 & .065 & -.053 & & & & & \\
\hline CD & .012 & .064 & .013 & & & & & \\
\hline FR & .110 & .054 & $.127^{*}$ & & & & & \\
\hline IS & .180 & .064 & $.208^{* * *}$ & & & & & \\
\hline N & $<.01 * * * 0$ & & & & & & \\
\hline
\end{tabular}

Notes: ${ }^{*} \mathrm{p}<.05 ; * * \mathrm{p}<.01 ; * * * \mathrm{p}<.001$

Gen $=$ Gender; Edu=Educational Level; Pos= Positional Tenure; Org=Organizational Tenure; Rec=Recognition;

$\mathrm{CD}=$ Competence Development; $\quad \mathrm{FR}=$ Fair Rewards; IS=Information Sharing 
Table 7. Results of the Hierarchical Regression Analyses for Human Resource Practices on Normative Commitment

\begin{tabular}{|l|c|c|c|c|c|l|l|l|}
\hline $\begin{array}{l}\text { Independent } \\
\text { variables }\end{array}$ & $\begin{array}{c}\text { Unstandardized } \\
\beta\end{array}$ & $\begin{array}{c}\text { Standard } \\
\text { error }\end{array}$ & $\begin{array}{c}\text { Standardized } \\
\beta\end{array}$ & R Square & $\begin{array}{l}\text { Adjusted } \\
\text { R Square }\end{array}$ & $\begin{array}{l}\text { R Square } \\
\text { Change }\end{array}$ & $\begin{array}{l}\text { F } \\
\text { change }\end{array}$ & $\begin{array}{l}\text { Sig.F } \\
\text { change }\end{array}$ \\
\hline Model1 & & & & 012 & -.006 & .012 & .662 & .680 \\
\hline Gen & -.023 & .072 & -.018 & & & & & \\
\hline Age & -.304 & .338 & -.052 & & & & & \\
\hline Edu & .032 & .084 & .021 & & & & & \\
\hline Pos & -.194 & .176 & -.067 & & & & & \\
\hline Org & -.009 & .111 & -.006 & & & & & \\
\hline Model2 & & & & .113 & .086 & .101 & 9.346 & .000 \\
\hline Gen & -.105 & .070 & -.081 & & & & & \\
\hline Age & -.117 & .327 & -.020 & & & & & \\
\hline Edu & .061 & .081 & .040 & & & & & \\
\hline Pos & -.210 & .169 & -.072 & & & & & \\
\hline Org & -.020 & .107 & -.014 & & & & & \\
\hline Rec & -.012 & .052 & -.016 & & & & & \\
\hline CD & -.009 & .051 & -.012 & & & & & \\
\hline FR & -.049 & .043 & -.070 & & & & \\
\hline IS & .250 & .051 & $.359^{*} * *$ & & & & \\
\hline
\end{tabular}

Notes: ${ }^{*} \mathrm{p}<.05 ; * * \mathrm{p}<.01 ; * * * \mathrm{p}<.001$

Gen $=$ Gender; Edu=Educational Level; Pos= Positional Tenure; Org=Organizational Tenure; Rec=Recognition;

$\mathrm{CD}=$ Competence Development; $\quad \mathrm{FR}=$ Fair Rewards; IS=Information Sharing 